\title{
NOWHERE IS BETTER THAN HERE: THE STRENGTHS AND WEAKNESSES OF EARLY SIXTEENTH CENTURY UTOPIAS
}

\author{
TIM NOBLE ${ }^{*}$ \\ International Baptist Theological Study Centre, Amsterdam \& Charles University, Prague
}

\begin{abstract}
This article examines the utopian vision present in the eponymous work by Thomas More and in the early Anabaptists. In the light of the discussion on the power and dangers of utopian thinking in liberation theology it seeks to show how More struggled with the tension between the positive possibilities of a different world and the destructive criticism of the present reality. A similar tension is found in early Anabaptist practices, especially in terms of their relationship to the state and their practice of commonality of goods. The article shows that that all attempts to reduce visions of a better world to a particular setting end up as ideological.
\end{abstract}

KEY WORDS: Anabaptists, Thomas More, utopianism, liberation theology, hope

\section{Introduction}

In this article, I will examine the power of utopian ideas in the early sixteenth century, especially in the birth of the various forms of Anabaptist or Radical Reformation thinking of the period. I do this in conjunction with a look at Thomas More's seminal work Utopia. My aim is to show the positive and negative impacts of utopian thinking, and how both contributed especially to Anabaptist thinking on the relation between church and state. Although drawing on historical sources, the article is not primarily historical. Rather, the question of the role of utopian thinking in theology is addressed through the lens of its treatment in current liberation theology to see how such thinking is both necessary and limited. When utopias seek to be realised and lose their eschatological power of transformation, hope is ultimately destroyed and the will to transform is lost. So I will seek to show to what extent More and the early Anabaptists sought to allow the transformative

* TIM NOBLE (PhD 2009, Vrije Universiteit Amsterdam) is Associate Professor of Missiology at the Protestant Theological Faculty, Charles University, Associate Fellow of the Centre for Theology, Philosophy, and Media Theory of the Catholic Theological Faculty, Charles University, and Adjunct Supervisor at the International Baptist Theological Study Centre, Amsterdam. Email: tim@etf.cuni.cz. 
power of another possible world (Pires Rizatto 2003; Althaus-Reid et al. 2007) to operate, without it turning into another form of ideology.

Before I turn to the question of utopia, a brief word on the tentative relation between More and early Swiss Anabaptism is called for. I make no claims here for influence, but I do want to argue that it is at least plausible to suggest that people such as Balthaser Hubmaier or Conrad Grebel would have read More's work. Utopia was first published (in Latin) in Leuven in late 1516 or early 1517 (Lupton 1895: lxiv). What was meant to be the second edition-though in fact it was the third edition to appear-was a version revised by More that appeared in Basle in 1518 (Lupton 1895: lxvilxx). This edition was printed by Johannes Froben at the instigation of Erasmus, a close friend of Froben and godfather to his son.

Both Grebel (Bender 1998: 14) and Hubmaier (Bergsten 1978: 73) had contacts in Basle and with Erasmus, though in both cases later than the publication of Utopia. Given how highly Erasmus rated More's work, it is a reasonable assumption that it would have come up in discussion and though not directly a source of any strand of Anabaptist thinking, it does offer an insight into the contemporary desire for a transformed social imaginary (Taylor 2004). As a German scholar of Anabaptism has put it,

It is not by chance that this [utopian] thinking gained new impulses with Thomas More's Utopia in a time of civil conflict and radical religious transformation, which have had a lasting effect on European-Atlantic history... Sixteenth-century Anabaptism [Täufertum] can above all be considered under the historical theme of social alternatives (Goertz 1988: 9).

\section{Liberation Theology on Utopia}

As a hermeneutical key for reading these utopian visions, I turn to liberation theology. This theology developed in Latin America in the late 1960s and 1970s, in a context where the vast majority of people professed themselves to be Christian, as a form of protest against social oppression and inequality. From the very beginning (Gutiérrez 1973) the theology of liberation sought not only to articulate the desire of God to liberate his people from oppression but to develop a vision of the Kingdom of God into which the whole of creation is called. Despite criticisms from the Vatican (Instruction 1984) and others (Novak 1986) about the alleged Marxist inspirations of these new social visions, liberation theologians have continued to insist that their thinking about social transformation is firmly based in the gospel and Christian tradition (Boff and Boff 1984).

The most comprehensive treatment of utopian thinking in liberation theology remains that of the Brazilian Jesuit theologian João Batista Libanio, in a book and long essay (Libanio 1989 and 1992). As I have dealt with this in more detail elsewhere (Noble 2013: 52-60), I offer here only a brief 
summary of Libanio's position. He begins with an allusion to the GermanAmerican Marxist writer Herbert Marcuse, who, in a lecture delivered in Berlin in 1967, had argued that in modernity only what is against the laws of nature would be utopian, but that the means for transforming society exist and are not contrary to the laws of nature, and thus utopian thinking is past (Marcuse 1970). But Libanio wants to go beyond Marcuse's narrow argument to argue that in modernity the need for anything transcendental has been abandoned-we are in a strong sense self-sufficient (Libanio 1992: 496). Against this he wants to argue that in Latin America and other contexts where poverty and oppression dominate, the need for utopias remains strong.

Libanio begins his discussion with a consideration of the dual etymology of the word utopia. Originally it seems to have been a suggestion of Erasmus to give a Greek name to More's original Latin Nusquama (Baker-Smith 2011: 143), and thus both meant 'Nowhere' or 'Noplace', ouk-topos. However, fairly early on it seems to have struck readers that there was another way of understanding the title, as a place of perfection and well-being. So, for example, the first Italian translation by Ortensio Lando, which appeared in Venice in 1548, referred already to Eutopia (eutopos) (Greengrass 2015: 179). Thus, Libanio argues that utopia always contains a double meaning, of critique and of promise. It is, we could say, a prophetic genre, where we find the condemnation of what is and the promise of what repentance-metanoia, (re)turning to God-will bring.

This dual element will be crucial in our examination of More's own work and of some of the early Anabaptists. For Libanio, what prevents utopias from becoming ideologies is the presence of hope, which he understands in an eschatological sense. That is to say, hope is certainly a present experience, and one based on experiences that the promises are at least partially fulfilled. But at the same time, it is a commitment to a future that is always still to come. Hope is open but grounded, refusing to accept any human social reality as the final possibility or the full manifestation of the Kingdom. To put this in more theological language, it accepts both the reality of human sinfulness and the reality of the overcoming of the power of $\sin$ through the life, death and resurrection of Jesus Christ.

This open-ended but not contentless nature of hope is important for Libanio because it prevents the ideologisation of a particular form of life. Any attempt to claim that a particular form of life or of church or of political settlement fully embodies all of the Kingdom is an ideology. As Libanio points out elsewhere (Libanio and Taborda 1992), ideologies are themselves born out of and often accompanied by utopian thinking. In this sense they can be regarded as positive, since they develop to challenge a particular status quo. Their problem and danger lies in the way in which they impose 
themselves not as alternatives to a status quo, but as a new and equally exclusive status quo. To do this is to deny hope, to claim that perfection has been achieved on earth.

This brief overview of a major treatment of utopia in liberation theology leaves me with two major tools for interpreting More and the early Anabaptists. The first will enable me to examine the tension present in their works between ouk-topos and eu-topos, between the unreal and the real. The former will critique the reality of the world in which we live, the latter will serve as an invitation to construct a new world. But, and especially in the second case, the appeal to the open-ended nature of hope reminds us that any attempt to reduce the good world that could exist to a given historical form will almost inevitably lead to ideology. So, my questions as I go back to the sixteenth century are to what extent More and the early Anabaptists realised this and to what extent they ended up forming new ideologies that ended up being, if not destructive, at least less life-giving than they had hoped.

\section{Thomas More: Indignation and Reimagination}

More's Utopia is one of the great humanist works of the sixteenth century. It remains, in the words of the literary critic Terry Eagleton, 'astonishingly radical stuff' (Eagleton 2015). It not only anticipates many different fantasy and sci-fi novels of the much more recent past, but it could quite plausibly be described as an early and in many ways very successful attempt at fake news (Baker-Smith 2011: 141-142). The book was written at a time when news of newly discovered lands was spreading fast (as Peter Giles mentions in his letter to Hieronymus Busleyden, a kind of preface to the book, Lupton 1895: xcix-c; More 2009: xv). [References are given to two versions of Utopia. The first, Lupton, contains the Latin text and the first English translation from 1551. The second, More, contains a translation by Paul Turner that renders the work into contemporary English. It is more accessible, if at times more of an anachronistic interpretation than a translation.]

It was only some 25 years after Columbus' first trip to the Americas, and indeed the name America was only just coming into use at this period, and Magellan's first circumnavigation of the world would not occur for another four or five years.

Within this framework of rapid expansion of European awareness about the size of the world, More purports to reproduce the words of one Raphael Hythlodaeus (Hythloday, which carries overtones of the Greek hythlos, nonsense, Baker-Smith 2011: 144). Raphael brings news of an island that he had visited on his travels, and in the second of the two books that make up the work, he describes in great detail the workings of the society. But the fact that this is a fictional account immediately raises persistent questions. As 
the political theorist Alan Ryan points out, the book really offers a debate between two sides of More's own character (Ryan 2013: 313). Is the fiction an excuse to avoid having to take responsibility for his ideas, is it a sign that he disagrees with Raphael's praise of utopian society, is it what we would now call indeed utopian, a vision of the way the world could be?

These questions are more than rhetorical, since they point to the ambiguities present in More himself, neatly presented in the two opposing characterisations of The Man for All Seasons (Bolt 1980) and Hilary Mantel's Wolf Hall and Bring Up the Bodies (Mantel 2009 and 2012). For a modern reader, More's Utopia can be disconcerting, not only for the obvious aspects like the acceptance of slavery as a form of legal punishment. It proposes a communitarian lifestyle that appears at times to be bordering on the totalitarian. But of course More is not writing for the twenty-first century, and as with any form of imagining, his world seeks to overcome the worst excesses of his own time and the reality that he knows. Thus, his insistence on the absence of money, on sufficiency of food and drink, on the unpleasantness of war. As a lawyer, More may favour a society based on justice above all, but in a world where justice for the ordinary person scarcely existed, certainly in terms of social relationships, this is not necessarily a bad thing.

Thus, the world that More imagines is an ordered one. As church historian Richard Rex points out, it was this attachment to a society that was properly and justly organised that lay behind his opposition to new forms of religious thinking that were developing in his time-what today we call the Reformation (Rex 2011: 97-98). More's condemnation of Protestantism is concerned as much with its rejection of authority as anything else. Thus he emphasises what liberation theologians would call orthopraxis as the basis of Christian faith. It is neither the written word nor the spoken word that are fundamental for true Christian living, but adherence to the practices of the church (Duffy 2011: 197-198). This at least is in keeping with the argument of Utopia, where it is the way that people live that matters most.

So we can assume that More wanted to create a world in which there was justice in terms of the practices of society, and that to the extent that this is revealed in Utopia he thought that it was in theory possible to develop such a society, even if in practice, as the ending makes clear, he acknowledged that it was extremely unlikely (Lupton 1895: 308-309; More 2009: 134-135). But what kind of world was this? The fact that More makes of Utopia an island is clearly not accidental, and the isthmus that separates it from the mainland is not wholly dissimilar in size to the English Channel. Moreover, the fifty-four cities of which it is comprised may well be a reflection of the counties of England and Wales at this time (Lupton 1895: 119). The geographical setting is such that comparisons with his own country are inevitable. 
The problems with Utopia begin with its foundation, based on conquest and imposition of a form of government on the indigenous peoples. Moreover, so the book tells us, the state continues to expand by conquest when it requires new territory. The act of foundational and ongoing violence is not much remarked upon in Utopia, and yet it hovers over the whole story. Whether More is to be taken as a kind of proto-Hobbesian is a moot point, but given that the state of English society did not significantly improve over the following century and a half, and indeed grew worse with the English Civil War, we may at least assume that Hobbes saw the same problems as More did and set about finding a solution in a similar way.

However, More's society in Utopia goes far beyond the sovereign power envisaged by Hobbes. Utopian government is based to a large extent on something like the principle of subsidiarity. This was developed in Roman Catholic social teaching in the first part of the twentieth century, as an alternative to centralising tendencies in government. The basic idea is that decisions should be taken and implemented at the appropriate level of government, and that the centre should leave as much as possible to the periphery (see on this McIlroy 2003). In Utopia the basic unit is the household, and thirty such households come under the authority of a Syphogrant (translated by Paul Turner in More 2009: 53 as 'Styward', given that suphos in Greek means 'sty' and the obvious pun on 'steward'). Each group of ten syphogrants is under a Tranibore ('bencheater'), and in each city these people come together to choose by secret ballot a Prince (essentially a mayor). There is a council for the whole island, but it is very little commented on, partly because we are told that there is very little need for legislation on the island (Lupton 1895: 234; More 2009: 98). Its main task is to run the planned economy efficiently (Lupton 1895: 169-170; More 2009: 68)

Legislation is largely redundant because of the absence of money. The complaint in Book One of Utopia about the injustices of the social system in England, where the rich prosper and the poor are punished, lies behind this radical commitment to an economy where all work for the good of all and thus there is ample sufficiency. The standard of living can perhaps best be summed up in words of Leon Bloy, cited by Clodovis Boff: 'Misery is the lack of what is necessary; poverty is the lack of what is superfluous'. Boff comments: 'The one is a mutilation; the other a virtue' (Boff 1987: 20). In other words, people have all they need, but they need only food, clothing and housing and there is plenty of all three as all contribute to producing them. Even though the weaknesses of planned economies are clear in practice, the utopian system remains an attractive one. Indeed, when the adjective 'utopian' is used today, it often implies some such system. The same idea was picked up by the nineteenth-century English writer and craftsman 
William Morris in his News from Nowhere (Morris 2004) and is found in other representations of ideal societies.

Given this lack of private property, and thus strictly speaking the impossibility of theft, it is not surprising that there is very little crime on the island. In fact, what is surprising is that there is any, but the fact that people are punished by the imposition of slavery makes it clear that More expects crime to endure. This can and perhaps should be attributed to a good Augustinian predilection for the ubiquity of original sin, and indeed the major possibility of crime seems to lie in committing adultery. But another major crime is rather more perplexing, in that people are not allowed to travel freely outside their districts except with permission from the magistrates (Lupton 1895: 168; More 2009: 67).

Although an apparent underside of subsidiarity, and more akin to a form of divide and rule, this emphasis is probably best understood against the backdrop of the perceived problem of vagrancy in sixteenth-century England. People wandering around doing nothing are not contributing to the maintenance of an ordered society, at least not as More envisaged it, and thus such behaviour is to be condemned. It has been argued that the first English translation of Utopia, by Ralph Robynson, published in 1551, was itself a response to the problem of vagrancy (Bishop 2011). At least it is clear that anyone who travels in Utopia is duty-bound to work for their board and lodging, and as long as they do that, they have no need of anything, because all will be provided on their travels as at home.

In terms of the treatment of warfare, More supplies the Utopians with something like a halfway house between pacifism and militarism. That is to say, the Utopians are ready, if necessary, to engage in warfare, but they try to avoid it as much as possible, and if they do have to fight they try to reduce the human cost. Thus, they endeavour not to use Utopian soldiers, but instead employ mercenaries to do the fighting for them. And even these they seek not to endanger. They prefer to gain military victories through strategical thinking that avoids direct engagement, and they do not permit slaughter of their opponents-here again we see the close connection between the Utopian and the Eutopian, between a critique of what is and a desire for what could be. The major interest in this chapter on warfare, since war necessarily requires interaction with others, and in this context other nations, is in how a purportedly perfect society engages with imperfection (Avineri 1962). This may explain why More strives to argue for an oxymoron, a more humane form of warfare.

The final area of life in Utopia which requires comment before turning to the Anabaptists is that of religion. As More would later be canonised as a saint in the Roman Catholic church, it may come as something of a surprise to see how he treats religious matters in Utopia. As James McConica, writ- 
ing on More's humanism, puts it: 'The reader of Utopia should be aware that the ideal society presented in Book II by a famously Christian author is in some respects strikingly at odds with Christian ideals' (McConica 2011: 39). In his discussion of religion, More undoubtedly adopts a position that reflects the humanism of his day. By using the dialogue form, he manages to absolve himself of defending the religious forms of Utopia, since these are given as simply a report by Raphael Hythloday. To some extent, also, More covers himself, by claiming that the Utopians, when they heard about Christianity, were quick to adopt it.

But a striking feature of Utopian religion is its tolerance. Most people, we are told, believe in a Supreme Being, called the Parent ('hunc parentem vocant', Lupton 1895: 267), to whom they apply the name Mythras. The differences are in precisely how they understand the role of this Supreme Being. But More devotes a fairly lengthy passage to a powerful defence of the need and importance of religious freedom, predating other such defences (Helwys 1998: 53-54) by almost a century. The argument comes from his belief (see Lupton 1895: 271, footnote 1) that truth will prevail, and that each person should be free to hold their own religious beliefs and even free to try to convince others of them, but always without resort to violence or force. The one thing that is not permitted in public is rejection of any idea of an afterlife or immortal soul. This is for political reasons, since it is assumed that without belief in the afterlife people will have no reasons to act for the common good. But even here, we are told that in private people are perfectly entitled to discuss such matters, and even encouraged to do so, since this is likely to help them in coming to the truth.

What then can we take from this brief discussion of Utopia? The second book, presenting the ideal society of the island of Utopia, can be read in various ways. It can be read as a commentary on Plato's Republic, or as something like a development of a vision of society from behind a Rawlsian veil of ignorance (Rawls 1999). It could simply be read as a humanist jeu d'esprit, in which More delights in arguments for their own sake. But it seems to me that it is best to take it as a real debate within More himself, between the demands of statecraft and the need to deal with the social evils of his time. There are serious points to be made in the book about the dangers of religious intolerance, about the pernicious effects of private property, about the cruelty of warfare and the horrors of poverty. Recalling Libanio's comments on the need to balance the power of utopian visions with the disrupting balance of eschatological hope, we can see More as attempting to do something similar. He wants to point to another possible and better world, but he also realises that Utopia must remain nowhere, because in the actual world it is not going to happen, and perhaps he also realises that if it 
did the costs of loss of freedom for the individual for the good of society may be higher than any given individual would wish to pay.

\section{The Utopian Vision of the Early Anabaptists}

The link between More's Utopia and the early Anabaptists (on the polygenesis of early Anabaptists, see Stayer et al. 1975) remains tenuous if plausible, as already pointed out. However, in as far as More referred to the Anabaptists, it was entirely negatively (Yoder 1992). Nevertheless, both More in his Utopia and many among the early Anabaptists shared both a disquiet with the contemporary state of the world, both religious and socio-economic, and a profound desire for a better world. In this section, then, I turn to the manifestations of this desire in early Anabaptist writers, in relation to social organisation, the state and religion.

From the Anabaptists' perspective, the religious question was the most important, and the struggle lay in rival biblical hermeneutics. But this was really More's major criticism, for he felt the social threat of a small group of individuals assuming - against the state or the church-the task of determining what the true meaning of the Scriptures was (Yoder 1992: 55-56). The threat of the Anabaptists (of the Reformation in general, in fact) was for More primarily a social one, and thus it makes sense to look first at the socio-economic implications of the path chosen by the early Anabaptists.

Different groups pursued common ownership of goods in markedly diverse ways (Goertz 1988: 31-33; Estep 1996: 98-99 and 127-149; Scribner 1994: 744-747). As in many other things, the individual groups differed in their interpretations of the import of the example of the early church recorded in Acts 2:44-45 and 4:34-35. This in part depended on which of these passages they gave most weight to, and at least among early Swiss Anabaptists, the claim was that they sought to share with those in need (Estep 1996: 40). There is no mention of sharing property and possessions in the Schleitheim Confession of 1527.

However, there were others for whom the joint pooling of resources was very important. Although in their most developed form they date to a somewhat later period, the best example here is the Hutterite communities that grew up in different parts of Moravia in the second half of the sixteenth century. One of the important early Hutterite theologians, Peter Riedemann (Friedmann 1959), offered an explanation for the common ownership of goods in his work Rechenschaft unser Religion (usually known in English as the Hutterite Confession). Riedemann writes that

[b]ecause all God's gifts, not only the spiritual but also the temporal, have been given to human beings to have not for themselves but for their brothers and sisters (Genossen), so it is that the Community of the Saints should be preserved, not only in spiritual but also in worldly things (Acts 2 and 4), so that, 
as Paul says, no one should have an over-abundance whilst another is in want (2 Corinthians 8), but that both should have the same (Riedemann 1974, cited in Goertz 1988: 180).

Whilst the reasoning is biblical, the precise form of how to live out the interpretation demanded more. For the New Testament record can be, and has been read differently, but any decision to try to live by it means adopting a particular form of life, which is at the very best hinted at in the short summaries of Acts, which themselves seem to serve as a kind of utopian vision of what might have been, rather than a faithful representation of the church(es) of the time of Luke.

Such attempts to form communities where none held anything in private were, needless to say, fraught with problems, not least because the Anabaptists had to interact with a society that did not practice such a lifestyle (Scribner 1994). The problems are seen at their starkest in the period of the Anabaptist rule in Münster in 1534-1535. However, it is reasonable not to regard Münster as typical or exemplary of Anabaptist ideas on community of goods, and rather to see it as demonstrating what could have happened if these ideas had not been so robust and well-grounded. As Scribner (1994: 758) puts it with some understatement: 'The Munster experiment and its outcome were certainly very different from the forms of community of property practised before and after by most other Anabaptists.'

Much more valid for considering the way in which some early Anabaptists practised community of goods is the Hutterite mode mentioned above. This ultimately developed out of a disagreement and subsequent disputation between Hans Hut and others on the one side and Balthasar Hubmaier on the other (Bergsten 1978: 361-365), when the Anabaptists were to all extents and purposes the established church (Klinedinst 2009: 519) in Mikulov (Nikolsburg) in what is now south-east Moravia. This is worth bearing in mind, since at least some of the Anabaptist practices were driven by necessity as much as by choice, and when the possibilities were open for different forms of behaviour they were not always ignored. Whatever the reasons, one of the points in the disputation between Hut and Hubmaier was to do with the question of private property (Goertz 1988: 114-116), linked to Hut's views on the extreme imminence of the Parousia.

Somewhat later, in the mid-1530s, the remnants of the group that had followed Hut and Jacob Wiedemann in Nikolsburg, and had been consequently expelled, were joined by Jakob Hutter, who gave his name to the Hutterite movement (Estep 1996: 127-134). Following Hutter's execution in 1536, the community based in Hustopeče (Auspitz) made the decision to continue. It grew over the next century, with periods of severe persecution intermingled with times of peace, till at its peak there were some $70 \mathrm{com}$ munities and perhaps up to 40,000 members of the group (Scribner 1994: 
760-761). Each of these communities was known as Bruderhof (or also Haushaben). Each Bruderhof probably contained between 400 and 600 people. The lifestyle was heavily communitarian, to such an extent that one author has commented that the Bruderhof 'symbolized the victory of the community over the family' (Stayer 1991: 145, cited in Scribner 1994: 762). In both the size of the settlements, comparable to groups under a single Syphogrant (More 2009: 61; Lupton 1895: 154), and in the forms of community life, there are considerable similarities to More's Utopia.

As noted already, although eschewing the use of money among themselves, they had to engage with a wider world, to sell their produce (particularly in Moravia their wine and pottery) and to buy what they could not produce for themselves. Because of the economy of scale and the fact that the labour force did not need paying (again similar to Utopia), the Bruderhofs were economically successful (Goertz 1988: 32), in a not dissimilar way to the Jesuit Reductions in Latin America in the following century and a half (Lugon 1949: 109). It was in part this factor that led to their persecution and eventual expulsion from Moravia. Any attempt to implement a utopian vision brings with it a threat to the status quo and to those outside the utopian world, and because in this case it was an economic threat it was almost inevitable that there would be repercussions.

Linked to the question of commonality of goods is the nature of the relationship to the state. The utopian vision here is not generally so much of a perfect state, but of the ability to live in a strict sense anarchically, with no centralised outside authority. The most common term used in German by the Anabaptists for such a body was Obrigkeit, best translated as 'authorities', and including the root idea of those who are placed over others. That is to say, the question is not how to participate in a democracy, but what attitude to take towards those who are placed or place themselves in positions of juridical authority over others. Phrased like this, it becomes clear that the attitude to civil authorities was related to the attitude to church authorities, either the Roman Catholic system or the Lutheran one (Goertz 1988: 110).

The major Anabaptist position from the beginning was one of deep reserve towards the civil authorities. The Schleitheim Confession, issued in 1527 by a group of early Swiss Anabaptists, and written by Michael Sattler, already contains a rejection of civil authority as part of the world from which true Christians should be separated (Sattler 1527: 12-13). This is based on a heavily dualistic view of a world divided into good and bad, and the desire to follow only the good. This is the extreme response to the kind of world that More bemoans in the first book of Utopia, in which the majority of the world (the 'real' world) is rejected as a no (or evil) place, as in a certain and quite strong sense non-existent. At the same time, the Confession very clearly rejects any recourse to violence-not using the sword or 
any other weapon and not resisting evil. It also rejects the possibility of any Christian serving in a position of civil authority. In doing so, it suggests that there is another world in which violence is not needed and in which there is no need for civil authority, because people will live in peace and harmony. It was this implication of a better world, among other things, that would lead to Sattler's execution shortly after the publication of the Schleitheim confession.

The other, minority, Anabaptist position was that adopted by Balthasar Hubmaier in his short work Von dem Schwert [On the Sword] (Hubmaier 1962: 434-457). In this text Hubmaier addresses the arguments of his opponents and attempts to show that participation in civil government is not only possible but a duty for Christians. Servants of the gospel should not engage in such activities (Hubmaier 1962: 452), but in general Hubmaier's view is that, given that in fact authorities exist, it is better if the positions of power are filled by good Christians, who will seek to act justly. It is important to stress this point. Hubmaier certainly does not offer a carte blanche to any form of civil government, and his position is probably as utopian as Sattler's. It is true that he engages in enough Realpolitik to accept that governments will exist and that violence will happen, but he is convinced that any punishment should only be to serve the needs of justice. Here he is in close agreement with More, who also sought to establish an overriding commitment to justice as the base for society in Utopia.

The final area of life that calls for some comment is the relation of early Anabaptists to religion. Hans Goertz argues that the 'Anabaptists, in protest against the abuses of the Middle Ages and the disappointments of the Lutheran and Zwinglian reformations, sought for new forms of religious communication and social order' (Goertz 1988: 9). Although they introduced some new articulations of Christian doctrine and some new emphases, they were chiefly concerned with what were essentially matters of church practice, to do with the significance of baptism, the meaning of the Lord's Supper, the structure of the ecclesial community. These, allied with an often very strong eschatological bent and chiliastic preferences, marked their deliberations and the way they sought to establish their communities.

In general, they were always in a difficult position when it came to supporting religious tolerance, since they needed and desired it for themselves, but were not so tolerant of the abuses of others. Nevertheless, and perhaps making a virtue out of necessity, they refused to sanction the violent persecution of people who held other beliefs. At his trial, Michael Sattler, author of the Schleitheim Confession, was accused among other things of saying that he would not fight against the Turks if they invaded, and that if anything he would march out alongside them rather than so-called Christians. His justification for this was that the Turks were ignorant of Christianity 
and were 'Turks according to the flesh', whilst so-called Christians (his judges) were 'Turks according to the Spirit', because they sought to 'persecute the pious witnesses of Christ' (Estep 1996: 71). There was an overarching commitment to witness to their faith that was borne out in their missionary activity (Godwin 2012) and in their non-violent responses to the hatred and vilification that was one of the few things to unite Catholics and Protestants during that period.

\section{Conclusion}

The aim of this article has been to examine the way in which utopian ideals informed two very disparate contexts in the early sixteenth century. My argument does not depend on any direct link between More's Utopia and the early Anabaptists, however plausible it may be to claim such a link. My main interest has been, rather, in addressing a kind of utopian Zeitgeist, dependent on the new energy given by humanism, and further influenced by the Reformation, beginning with Luther but particularly that of Zwingli in Zurich. The ressourcement of the Reformation was not just about retrieving a former golden age, but at the same time about imagining an equally golden future.

More's work alternates between a negative assessment of the present and the dream of another possible world, and this tension is also to be found in the Anabaptists. Their critique of the 'world' is a rejection of all that they disliked in what they saw around them, in the church, both Roman Catholic and Lutheran, in the arbitrary way in which justice was, or more frequently was not, administered, in the economic effects of early modern capitalism. In this they had much in common with More. And as with him, their critiques implicitly or at times explicitly suggested how things could be. Their stance against the state authorities is a good example of this, since this was what placed them most at odds with the Catholics and the classical Reformers, who were both, in their view, in too close a relationship with the governing bodies. They did not think that the 'state' had to be the final arbiter in a Christian's relationship with God, and many of them did not believe that violence was the answer to any problem that presented itself. But this negative belief went hand in hand with a belief in the real possibility of living in peace and harmony, of restoring shalom to the world. And that is undoubtedly utopian.

But just as More's Utopia is a (no) place that is, at least to modern readers, often deeply problematic, there are difficulties with the Anabaptist position too. Although it is true that we need to examine both More and the Anabaptists within their given historical and social contexts, this does not mean that we cannot find them wanting, precisely because they are bound by the world around them. More's Utopia presents, for us today with our 
more individualist understanding of human existence, a partly nightmarish existence. Slavery is used as a punishment, there is little freedom, and the pursuit of pleasure is highly communal. Not all of this is necessarily wrong (the communal aspect especially may be worth considering), but it is not what many of us would choose. And yet it is also a warning against the effects of the very individualism that we want to defend. It points to the fact that we are in relationship with others and bound to them. In an important way our lives are not our own.

But More's own problem with Utopia, expressed at the end of the book, is not to be ignored. In a perfect world, how do we find space for the idea of transcendent hope? The reading of utopia by Libanio, with which I began, pointed out that when we perceive ourselves as having achieved perfection, we end up creating an ideology because we lose the dimension of eschatological hope that leaves any vision of an alternative open-ended. And ideologies by definition are closed. More saw in his description of Utopia something good and desirable, certainly, but he also recognised that in the real world in which he lived, it could end up being as destructive as the world that he criticised and found unacceptable. The loss of freedom, the unwillingness to commit that is the other side of tolerance, the dependence always on the cooperation of others, were all too risky in a world that is marked both by the salvific action of Christ but also by the Fall.

The same problem confronted the Anabaptists. It is all very well to deny the authority of the state, to refuse to engage in the more questionable activities of the 'world'. The fate of Münster is an unfair example, but in fact many of the early Anabaptist communities faced problems too, as we saw with Hubmaier in Nikolsburg. The tyranny of the individual, the charismatic leader, or the community is not always less destructive than the tyranny of the state, even if its effects are generally more limited. The potential violence of the Anabaptist position should not be underestimated either. This is perhaps most evident in the practice of the ban (Smith 2010). Here exclusion becomes a weapon to enforce compliance and conformity that goes against the vision of a better and different world. A genuine conviction that a given position is the only correct one leads frequently to an ideological insistence on everyone holding that position. Again, the examples are present in Anabaptist history and arguably, for us today and perhaps for More himself, in Utopia.

The utopian vision remains then an intriguing one, but one that is always fraught with danger. Whatever relation they had or did not have to Thomas More's book, the early Anabaptists embodied a form of utopianism in their thought and in their practices. Although they could not avoid the problems and found it hard to allow the troubling disturbance of a genuinely open-ended eschatological hope to question their vision, they provide an 
example of a group of communities who, when at all possible, tried to implement an alternative way of life (Goertz 1988: 13-42). As with More and his work, the power of their alternative vision has continued to inspire people and to allow Christians in many different places and contexts to think that the world could be different and better. Although eschatological hope must remain open-ended and disruptive of any attempt to call a concrete form of life the Kingdom of God, Christians, as the Anabaptists showed, retain the prophetic task to work towards the implementation of the Kingdom in the power of the Holy Spirit.

\section{Bibliography}

Althaus-Reid M, Petrella I, and Susin LC, eds (2007) Another Possible World. London: SCM.

Avineri S (1962) War and Slavery in More's Utopia. International Review of Social History 7(2): 260-290.

Baker-Smith D (2011) Reading Utopia. In Logan GM (ed) The Cambridge Companion to Thomas More. Cambridge: Cambridge University Press, pp. 141-167.

Bender H (1998) Conrad Grebel. The Founder of the Swiss Brethren. Eugene, OR: Wipf and Stock.

Bergsten T (1978) Balthasar Hubmaier. Anabaptist Theologian and Martyr. Valley Forge, PA: Judson Press.

Bishop J (2011) Utopia and Civic Politics in Mid-Sixteenth-Century London. The Historical Journal 54(4): 933-953.

Boff C (1987) Feet-on-the-Ground Theology: a Brazilian Journey. Maryknoll, NY: Orbis.

Boff L and Boff C (1984) Cinco Observações de fundo à intervenção do Cardeal Ratzinger acerca da Teologia da Libertação de corte marxista. Revista Eclesiástica Brasileira 44(173): 115-120.

Bolt R (1980) A Man for All Seasons. London: Heinemann.

Duffy E (2011) 'The comen knowen multytude of crysten men': A Dialogue Concerning Heresies and the defence of Christendom. In Logan GM (ed) The Cambridge Companion to Thomas More. Cambridge: Cambridge University Press, pp. 191-215.

Eagleton T (2015) Utopias, past and present: why Thomas More remains astonishingly radical. The Guardian 16.10.2015, https://www.theguardian.com/ books/2015/oct/16/utopias-past-present-thomas-more-terry-eagleton (Accessed 22 June 2017).

Ellacuría I and Sobrino J (1992) Mysterium Liberationis: conceptos fundamentales de la teología de la liberación, 2 vols. Second edition. San Salvador: UCA Editores. Partial English translation: Sobrino J and Ellacuría I 
(1996) Systematic theology: Perspectives from Liberation Theology. London: SCM Press.

Estep WR (1996) The Anabaptist Story. An Introduction to Sixteenth-Century Anabaptism. Third edition. Revised and enlarged. Grand Rapids, MI: Eerdmans.

Friedmann R (1959) Riedemann, Peter (1506-1556). Global Anabaptist Mennonite Encyclopedia Online, http://gameo.org/index.php?title=Riedemann,_Peter_(1506-1556)\&oldid=146153 (Accessed 26 June 2017).

Godwin C (2012) Baptizing, Gathering, and Sending: Anabaptist Mission in the Sixteenth Century Context. Kitchener, Ontario: Pandora Press.

Goertz HJ (1988) Die Täufer. Geschichte und Deutung. Berlin: Evangelische Verlagsanstalt.

Greengrass M (2015) Christendom Destroyed: Europe 1517-1648. London: Penguin.

Gutiérrez G (1973) A Theology of Liberation: History, Politics, and Salvation. Maryknoll, NY: Orbis Books.

Helwys T (1998) A Short Declaration of the Mystery of Iniquity. Groves R (ed), Macon, GA: Mercer University Press.

Hubmaier B (1962) Schriften. Westin G and Bergsten T (eds), Gutersloh: Gutersloher Verlagshaus Gerd Mohn.

Instruction on Certain Aspects of the 'Theology of Liberation' (1984) Congregation for the Doctrine of Faith, http://www.vatican.va/roman_curia/congregations/cfaith/documents/ rc_con_cfaith_doc_19840806_theologyliberation_en.html (Accessed 22 June 2017).

Klinedinst RJ (2009) Rethinking Politics as Statecraft: Wendell Berry Among the Anabaptists. The Mennonite Quarterly Review 83(4): 517-538.

Libanio JB (1989) Utopia e Esperança cristã. São Paulo: Edições Loyola.

Libanio JB (1992) Esperanza, Utopía. Resurrección. In Ellacuría I and Sobrino J (1992) Mysterium Liberationis, vol. 2. San Salvador: UCA Editores, pp. 495-510. English translation: Hope, Utopia, Resurrection. In Sobrino J and Ellacuría I (1996) Systematic Theology. London: SCM Press, pp. 279-290.

Libanio JB and Taborda F (1992) Ideología. In Ellacuría I and Sobrino J (1992) Mysterium Liberationis, vol. 2. San Salvador: UCA Editores, pp. 579-600.

Logan GM (ed) (2011) The Cambridge Companion to Thomas More. Cambridge: Cambridge University Press.

Lupton JH (1895) The Utopia of Sir Thomas More. Oxford: Oxford University Press.

Mantel H (2009) Wolf Hall. London: Fourth Estate.

Mantel H (2012) Bring Up the Bodies. London: Fourth Estate. 
Marcuse H (1970). The End of Utopia. In Five Lectures: Psychoanalysis, Politics, and Utopia. Shapiro J and Weber S (trans). Boston: Beacon, pp. 6281 .

McConica J (2011) Thomas More as Humanist. In Logan GM (ed) The Cambridge Companion to Thomas More. Cambridge: Cambridge University Press, pp. 22-45.

McIlroy DH (2003) Subsidiarity and Sphere Sovereignty: Christian Reflections on the Size, Shape and Scope of Government. Journal of Church and State 45(4): 739-763.

More T (2009) Utopia. Paul Turner (trans). London: Penguin.

Morris W (2004) News from Nowhere and Other Writings. London: Penguin.

Lugon C (1949) La République Communiste Chrétienne des Guaranís (16101768). Paris: Les Éditions Ouvrières, Économie et Humanisme.

Noble T (2013) The Poor in Liberation Theology. Ideological Construct or Pathway to God? Abingdon: Routledge.

Novak M (1986) Will it Liberate? Questions about Liberation Theology. New York: Paulist Press.

Pires Rizatto A (2003) III Fórum Social Mundial: um outro mundo é possível. Interface-Comunicação, Saúde, Educação 7(12): 167-168.

Rawls J (1999) A Theory of Justice. Oxford: Oxford University Press.

Rex R (2011) Thomas More and the Heretics: Statesman or Fanatic? In Logan GM (ed) The Cambridge Companion to Thomas More. Cambridge: Cambridge University Press, pp. 93-115.

Riedemann P (1974) Rechenschaft unsrer Religion, Lehre und Glaubens. Von den Brüdern, die man die Huterischen nennt. Cayley, Alberta: Macmillan Colony.

Ryan A (2013) On Politics: A History of Political Thought from Herodotus to the Present. London: Penguin.

Sattler M (1527) Brüderlich vereinigung etlicher Kinder Gottes / sieben artikel betreffend. Acta Schlatten am Randen auff Matthie, http://www.museumschleitheim.ch/ taeufer_bekenntnis2.htm (Accessed 27 June 2017).

Scribner R (1994) Practical Utopias: Pre-Modern Communism and the Reformation. Comparative Studies in Society and History 36(4): 743-774.

Smith PE (2010) The enthrallment of violence in Mennonite church discipline: An analysis of convictions in terms of peace and ecclesial practice. $\mathrm{PhD}$ Thesis, IBTS Prague-University of Wales.

Stayer J, Packull WO, Deppermann K (1975) From Monogenesis to Polygenesis: The Historical Discussion of Anabaptist Origins. Mennonite Quarterly Review 49(2): 83-121.

Stayer J (1991) The German Peasants' War and Anabaptist Community of Goods. Montreal: McGill-Queen's University Press.

Taylor C (2004) Modern Social Imaginaries. Durham, NC: Duke University Press. 
Yoder JT (1992) Thomas More and the Anabaptists. The Mennonite Quarterly Review 66(1): 47-56.

Acknowledgment: This article is part of the project 'Latin American Liberation Theology: Prospects and Challenges' (GAČR P401 / 18-01543S), funded by the Czech Science Foundation. 